This item was submitted to Loughborough's Research Repository by the author.

Items in Figshare are protected by copyright, with all rights reserved, unless otherwise indicated.

\title{
Study of temperature effect on macro-synthetic fiber reinforced concretes by means of Barcelona tests: An approach focused on tunnels assessment
}

PLEASE CITE THE PUBLISHED VERSION

https://doi.org/10.1016/j.conbuildmat.2017.10.046

\section{PUBLISHER}

(C) Elsevier

\section{VERSION}

AM (Accepted Manuscript)

\section{PUBLISHER STATEMENT}

This work is made available according to the conditions of the Creative Commons Attribution-NonCommercialNoDerivatives 4.0 International (CC BY-NC-ND 4.0) licence. Full details of this licence are available at: https://creativecommons.org/licenses/by-nc-nd/4.0/

\section{LICENCE}

CC BY-NC-ND 4.0

\section{REPOSITORY RECORD}

Rambo, Dimas A., Ana Blanco, Antonio de Figueiredo, Edson R. dos Santos, Romildo D. Toledo Filho, and Otavio Gomes. 2019. "Study of Temperature Effect on Macro-synthetic Fiber Reinforced Concretes by Means of Barcelona Tests: An Approach Focused on Tunnels Assessment”. figshare.

https://hdl.handle.net/2134/32293. 
1 Study of temperature effect on macro-synthetic fiber reinforced

2 concretes by means of Barcelona tests: an approach focused on tunnels

\section{assessment}

4 Dimas Alan Strauss Rambo ${ }^{\mathrm{a}, 1}$, Ana Blanco $^{\mathrm{b}}$, Antonio Domingues de Figueiredo ${ }^{\mathrm{a}}$, Edson

5 Rodrigo Fernandes dos Santos ${ }^{\mathrm{c}}$, Romildo Dias Toledo Filho ${ }^{\mathrm{c}}$ and Otávio da Fonseca Martins Gomes ${ }^{\mathrm{d}, \mathrm{e}}$

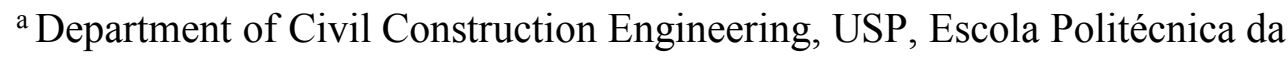

9 Universidade de São Paulo, Rua Professor Almeida Prado 532, São Paulo, 05508-901, Brazil.

${ }^{b}$ Department of Civil and Environmental Engineering, Universitat Politècnica de

${ }^{c}$ Civil Engineering Department, COPPE, Universidade Federal do Rio de Janeiro, P.O. Catalunya, UPC, Jordi Girona 1-3, 08034, Barcelona, Spain.

${ }^{1}$ Corresponding author: e-mail: dimasrambo@gmail.com, Phone: +55(11) 98699-0220.

Present address: Faculty of Technology and Exact Sciences, University São Judas Tadeu, USJT, Rua Taquari 546, CEP 03166-000, São Paulo - SP, Brazil. 


\section{Abstract}

23 This paper presents an experimental investigation on the applicability of the Barcelona

24 (BCN) test to evaluate the mechanical properties of a Macro-Synthetic Fiber Reinforced

25 Concrete (MSFRC) submitted to high temperature environments (up to $600^{\circ} \mathrm{C}$ ). $\mathrm{BCN}$ 26 tests demonstrated that the MSFRC gradually loses tensile strength an energy 27 consumption density with increasing temperature. Temperatures of $400^{\circ} \mathrm{C}$ and $570^{\circ} \mathrm{C}$ 28 shown to be critical to the MSFRC mechanical performance. The residual mechanical 29 behavior of the macro-synthetic fibers was not affected by the temperature up to $100^{\circ} \mathrm{C}$.

30 For higher temperatures, the reinforcement showed that may lose part of its crystallinity 31 compromising the MSFRC post-cracking performance. The constitutive model used to 32 determine the stress-strain curves of the MSFRC was capable to reproduce the composite 33 behavior after the event of a fire.

37 Keyword: Barcelona test; Elevated temperatures; Macro-synthetic fiber reinforced 38 concretes; Tunneling.

$40 \quad$ Highlights

41 MSFRC loses residual tensile strength and energy density with rising temperature.

42 Temperatures of $400^{\circ} \mathrm{C}$ and $570^{\circ} \mathrm{C}$ are critical to the MSFRC mechanical performance.

$43 \mathrm{Up}$ to $100^{\circ} \mathrm{C}$ the residual mechanical behavior of the macro fibers is not affected.

44 The specimen surface degradation caused by temperature affect BCN test result. 


\section{Introduction}

46 It is well known that a properly dosed concrete composite reinforced with macro-

47 synthetic fibers (i.e.: MSFRC) may be suitable for structural applications, presenting 48 ductility under compression and great energy absorption capacity under tension $[1,2,3,4]$.

49 Different from other fiber reinforced composites (e.g.: steel fiber reinforced concretes),

50 the mechanical behavior of a MSFRC is majorly dependent on the frictional bond 51 stablished between the fiber and matrix at the interfacial transition zone [5]. Such 52 characteristic led the macro-synthetic fibers to evolve in terms geometry, anchorage and 53 surface treatment.

54 In high temperature environments, however, the behavior of a MSFRC is dependent on 55 the thermal gradient established in the element, as well as on the mechanical and physical 56 changes occurred on both: fibers and matrix. This topic represent one of the main 57 unresolved and challenging issues regarding the performance of this composite that still 58 concern the scientific community and the construction sector. The effect of fire exposure 59 and elevated temperatures on the mechanical behavior of a MSFRC is particularly 60 interesting to the case of underground tunnel structures, which frequently employ this 61 type of material.

62 Once heated, a Portland cement concrete will experience several chemo-physical 63 transformations: release of free and chemically combined water, decomposition of the 64 calcium silicate hydrates $(\mathrm{CSH})$, dehydration of portlandite and decomposition of 65 carbonated phases. As a result, the concrete exhibits reduction of the tensile and 66 compressive strength, cracking, loss of the bond between the aggregates and the cement 67 paste, deterioration of the hardened cement paste and, in some cases, spalling [6]. The 68 addition of micro synthetic fibers (in particular the polypropylene fibers) may reduce the 
69 chance of concrete spalling [7] while macro fibers (e.g. steel, polypropylene), may

70 guarantee residual load-bearing capacity of the structure [8].

71 Such load-bearing capacity will depend on the type of fibers used, but certainly it will 72 contribute to reducing the risk of a tunnel collapse. This aspect is particularly relevant 73 considering the high costs associated to the reconstruction or repairing of a collapsed 74 tunnel $[9,10]$ and the historic sequence of catastrophic events occurred in such structures 75 submitted to fire loading [9].

76 Table 1 presents relevant data of previous studies on the effects of high temperature on 77 FRC, including the used type of fiber, the temperatures reached and the tests performed. 78 The notation used to distinguish the material of the fiber is: $\mathrm{C}$ for carbon, $\mathrm{S}$ for steel, $\mathrm{PP}$ 79 for polypropylene and PE for polyethylene. The symbol + is applied for hybrid 80 reinforcement (when more than one type of fiber is used in one mix).

\begin{tabular}{lcccc}
\hline Reference & Fiber & $\begin{array}{c}\text { Temperature } \\
\left({ }^{0} \mathrm{C}\right)\end{array}$ & Specimen (mm) & Tests \\
\hline Chen and Liu [11] & $\begin{array}{r}\mathrm{C}, \mathrm{S}, \mathrm{PP}, \mathrm{C}+\mathrm{S}, \\
\mathrm{C}+\mathrm{PP}, \mathrm{S}+\mathrm{PP}\end{array}$ & $\begin{array}{c}200,400, \\
600,800\end{array}$ & $100 \times 100 \times 100$ & $\begin{array}{c}\text { Compression and } \\
\text { splitting }\end{array}$ \\
\hline Peng et al. [12] & $\mathrm{S}+\mathrm{PP}$ & $400,600,800$ & $\begin{array}{c}100 \times 100 \times 100 \\
300 \times 100 \times 100\end{array}$ & $\begin{array}{c}\text { Compression } \\
\text { Bending and } \\
\text { explosive spalling }\end{array}$ \\
\hline Sukontasukkul et al. [8] & $\mathrm{S}, \mathrm{PP}, \mathrm{PE}$ & $400,600,800$ & $350 \times 100 \times 100$ & Bending \\
\hline Colombo et al. [13] & $\mathrm{S}$ & $\begin{array}{c}200,400, \\
600,800\end{array}$ & $500 \times 75 \times 60$ & Bending \\
\hline
\end{tabular}

\begin{tabular}{lllll}
\hline Choumanidis et al. [14] & S, PP, S+PP & 280 & $150 \times \emptyset 150$ & Barcelona test
\end{tabular}

83 Table 1 - Summary of previous studies on the effect of temperature on FRC

84 The data presented in Table 1 reveals that previous studies focus on the evaluation of the mechanical properties such as residual strengths or toughness indexes. However, the

86 microstructure of matrix and the damage suffered by the fiber, which are relevant 87 parameters to understand the composite mechanical behavior at high temperatures, are not evaluated.

89 This paper presents a comprehensive study of the effects of high temperature on MSFRC:

90 from the mechanical performance to the microstructure point of view. The goal was to 
91 establish the pattern of the degradation of the specimen along its central axis and, then, correlate it with the loss of mechanical strength.

93 The integrated analysis of the mechanical behavior with the characterization of the

94 damage that occurred in the microstructure provide a unique and novel insight into the

95 effects of high temperatures on the performance of MSFRC. Furthermore, the study also

96 sheds light into the applicability of the Barcelona test to evaluate the post-heating residual

97 strength of the material. In fact, this test is one of the few in the literature that can be performed on FRC specimens drilled from real structures that have been exposed to a fire.

\section{Experimental campaign}

100 The experimental campaign begins with the manufacturing and curing process employed

101 to the studied MSFRC. Mechanical tests were performed to assess the composite behavior 102 before and after heating. The MSFRC was evaluated with respect to the residual tensile 103 strength through the Barcelona test [15]. Pre and post heating compressive strength and 104 elastic modulus, were also determined. These evaluations provide conditions to assess the 105 influence of temperature on the behavior of the composite. In order to obtain a better 106 understanding of the effect of the temperature variation in the materials structure, tests 107 were performed to characterize the materials structures. The integrity of the fibers before 108 and after heat treatment was evaluated through direct tensile tests and Differential 109 Scanning Calorimetry (DSC). The fiber-matrix interfaces were assessed in all target 110 temperatures by means of a Scanning Electron Microscope (SEM). Such isolated

111 investigations (pre and post heating), represent key points while studying the residual 112 performance of a real structure. Finally, a well detailed explanation is given about the 113 materials characterization, which involves SEM, thermogravimetry (TG), differential 114 scanning calorimetry (DSC) and XRD analysis applied for both: MSRFC, paste and 115 macro-synthetic fibers. 


\section{$116 \quad 2.1 \quad$ MSFRC manufacturing and curing}

117 The concrete used in this research was developed using the same materials and mix-

118 design specified to the concrete matrix used to produce the tunnel segments of the "Metro

119 Line 6" under construction in the city of São Paulo, Brazil. The matrix was designed with

120 a High Early Strength Portland Cement (CP V - ARI RS), silica fume, two coarse

121 aggregates $\left(\mathrm{d}_{\max }: 19 \mathrm{~mm}\right.$ and $\left.\mathrm{d}_{\max }: 9.5 \mathrm{~mm}\right)$, artificial $\left(\mathrm{d}_{\max }: 4.8 \mathrm{~mm}\right)$ and river sand $\left(\mathrm{d}_{\max }: 2 \mathrm{~mm}\right)$

122 and a polycarboxylate-based superplasticizer (ADVA 525, Grace Company). The matrix

123 composition is summarized in Table 2.

124

\begin{tabular}{lc}
\hline Constituent & MSFRC \\
\hline Portland cement $\left(\mathrm{kg} / \mathrm{m}^{3}\right)$ & 400 \\
Granite coarse aggregate $\mathrm{d}_{\max }: 19 \mathrm{~mm}\left(\mathrm{~kg} / \mathrm{m}^{3}\right)$ & 770 \\
Granite coarse aggregate $\mathrm{d}_{\max }: 9.5 \mathrm{~mm}\left(\mathrm{~kg} / \mathrm{m}^{3}\right)$ & 330 \\
River sand $\left(\mathrm{kg} / \mathrm{m}^{3}\right)$ & 403 \\
Artificial sand $\left(\mathrm{kg} / \mathrm{m}^{3}\right)$ & 269 \\
Silica fume $\left(\mathrm{kg} / \mathrm{m}^{3}\right)$ & 22 \\
Water $\left(\mathrm{kg} / \mathrm{m}^{3}\right)$ & 165 \\
Water $/ \mathrm{cementitious} \mathrm{material} \mathrm{ratio}$ & 0.39 \\
Superplasticizer $\left(1 / \mathrm{m}^{3}\right)$ & 2.75 \\
Micro-synthetic fiber $\left(\mathrm{kg} / \mathrm{m}^{3}\right)$ & 0.8 \\
Macro-synthetic fiber $\left(\mathrm{kg} / \mathrm{m}^{3}\right)$ & 8 \\
\hline
\end{tabular}

125

126 Table 2 - Summary of the MSFRC composition.

127 The concrete matrix was reinforced with macro-synthetic fibers (BarChip48)

128 commercialized in Brazil by the EPC Group (Elasto Plastic Concrete) specifically for this

129 study. The real tunnel has adopted steel fibers combined with conventional reinforcement

130 to produce the pre-cast segments. Polypropylene micro-fibers, from the Brazilian

131 company Neomatex, were also employed in the mixture in order to inhibit explosive

132 spalling at elevated temperatures respecting the segments specification. The dosage and 
133 properties (supplied by the manufacturers) of both synthetic fibers can be found, 134 respectively, in Table 2 and Table 3.

\begin{tabular}{lc}
\hline Macro-synthetic fiber (reinforcement)* & \\
\hline Specific gravity & $0.90-0.92$ \\
Tensile strength (MPa) & 640 \\
Fibers/kg & 59500 \\
Youngs Modulus (GPa) & 10 \\
Melting point $\left({ }^{\circ} \mathrm{C}\right)$ & $159-179$ \\
Ignition Point $\left({ }^{\circ} \mathrm{C}\right)$ & $>450$ \\
Fiber length $(\mathrm{mm})$ & 48 \\
\hline
\end{tabular}

\begin{tabular}{lc}
\hline Polypropylene micro-fiber (anti-spalling)* \\
\hline Density $\left(\mathrm{g} / \mathrm{cm}^{3}\right)$ & 0.91 \\
Fibers $/ \mathrm{kg}$ & 130 millions \\
Melting point $\left({ }^{\circ} \mathrm{C}\right)$ & 165 \\
Fiber diameter $(\mathrm{mm})$ & $30 \mu \mathrm{m}$ \\
Fiber length $(\mathrm{mm})$ & 12 \\
${ }^{*}$ Data provided by the manufacturers &
\end{tabular}

*Data provided by the manufacturers

136 Table 3 - Properties of the used synthetic fibers.

137 Preliminary tests were carried out in order to define the reference matrix with the desired

138 macro fiber content $\left(8 \mathrm{~kg} / \mathrm{m}^{3}\right)$ and slump value $(\sim 8 \mathrm{~cm})$. The composite was prepared in a

139 conventional concrete mixer (300 l capacity) at a room temperature of $24^{\circ} \mathrm{C} \pm 1{ }^{\circ} \mathrm{C}$. First,

140 all aggregates were homogenized by dry mixing for 60 s prior to the addition of 141 cementitious materials ( +60 s of dry mixing). Water and superplasticizer were then slowly

142 added to the mixture, which was subsequently blended for 8 minutes. Both fibers were

143 manually incorporated into the mixture ( +5 minutes of blending). The concrete mixture

144 was cast in the steel molds $150 \times 300 \mathrm{~mm}$ (diameter $\mathrm{x}$ height) in two equal layers. The

145 concrete consolidation was carried out through a vibratory table $(60 \mathrm{~Hz})$ during $30 \mathrm{~s}$. 
146 The MSFRC was cured in a wide electric oven at $40^{\circ} \mathrm{C}$ during $24 \mathrm{~h}$ before demolding.

147 Before heating process, the specimens were sealed using a PVC film. After thermal cure,

148 cylinders were cut into two equal pieces (half of the height) in order to generated

149 specimens of $150 \times 150 \mathrm{~mm}$ (diameter $\mathrm{x}$ height) for the BCN test as well as prescribed by

150 the standard UNE 83504:2004 [16]. The specimens were then regularized and keep in dry

151 condition (sealed in plastic bags) for 28 days. Those conditions were the closest possible

152 to the segments production. In addition, $75 \times 150 \mathrm{~mm}$ (diameter $\mathrm{x}$ height) cylinders were

153 extracted from the aforementioned specimens in order to determine the composite

154 compressive strength and elastic modulus.

\section{$155 \quad 2.2 \quad$ Mechanical tests}

$156 \quad$ 2.2.1 Barcelona tests

157 The BCN specimens were submitted to indirect tension following the specification

158 prescribed on UNE 83515:2010 [15]. During the tests, the composites were subjected to

159 double punch test by means of two cylindrical steel punches centered on both upper and

160 bottom surfaces of the specimens (see Figure 1). The ratio between the specimen diameter

161 and the punch diameter was kept in 1:4, while the ratio between their respective heights

162 was 1:5. The total circumferential opening displacement (TCOD) values, were measured

163 at the middle height of the $\mathrm{BCN}$ specimens using a chain apparatus, connected to a clip-

164 gauge (Shimadzu Company) with a maximum range of $5 \mathrm{~mm}$, instead of the $10 \mathrm{~mm}$

165 required by UNE 83515 [15]. Thus, the residual strength and toughness values remained

166 restricted to a maximum TCOD of $4 \mathrm{~mm}$. 


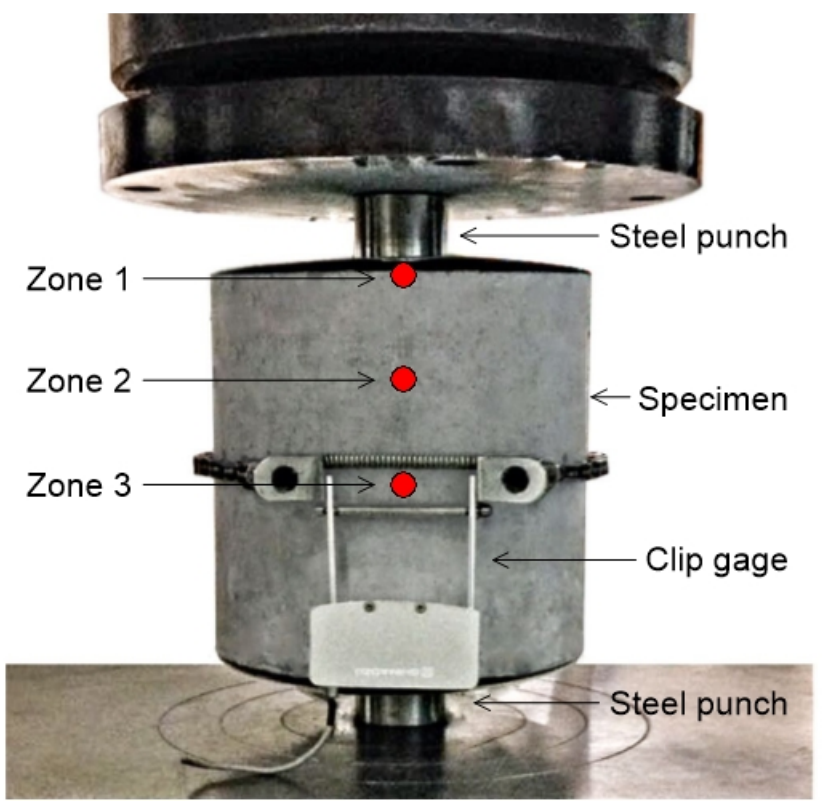

168 (Single column fitting image; preference for color: online only)

169 Figure 1 - Set-up of the BCN test and reference zones along the specimen central axis,

170 used for chemical and microstructural analysis.

171 The tensile strength of the produced MSFRCs was determined through the formulation

172 proposed by Blanco [17], which is analytically derived from the results of the test and

173 provides a $\sigma-\varepsilon$ relation that is valid for the linear-elastic and post-cracking stages. The

174 formulation to estimate the tensile stresses $(\sigma)$, shown in Eq. (1), is based on the balance

175 of forces interacting in the specimen. The strain $(\varepsilon)$ in the linear-elastic stage is obtained

176 as the tensile stress to the modulus of elasticity $(E)$ ratio. After the cracking, Eq. (2) is

177 used to estimate the strain. This expression was derived using the principle of the virtual

178 works.

$$
\begin{aligned}
\sigma & =\frac{F_{P}}{2 \cdot \pi \cdot A} \cdot \frac{\cos \beta-\mu_{k} \cdot \operatorname{sen} \beta}{\operatorname{sen} \beta+\mu_{k} \cdot \cos \beta} \text { with } A=\frac{d \cdot h}{4}-\frac{d^{\prime 2}}{4 \cdot \tan \beta} \\
\varepsilon & =\frac{n \delta_{P}}{\pi R} \cdot \tan \beta \cdot \sin \left(\frac{\pi}{n}\right)
\end{aligned}
$$


179 In Eq. (1) and Eq. (2), several variables are involved: the load applied during the test $\left(F_{P}\right)$,

180 the failure angle of the material $(\beta)$, the kinetic friction coefficient $\left(\mu_{k}\right)$, the diameter and

181 height of the specimen ( $d$ and $h$ ), the diameter of the steel punch where the load is applied

$182(d ')$, the number of cracks $(n)$, the radius of the specimen $(R)$ and the displacement

183 registered during the test $\left(\delta_{P}\right)$. Most of these parameters are directly obtained from the

184 results of the test $\left(F_{P}\right.$ and $\left.\delta_{P}\right)$, the geometrical characteristics of the specimen $(d=150$

$185 \mathrm{~mm}, h=150 \mathrm{~mm}$ and $R=75 \mathrm{~mm})$ or the test setup $\left(d^{\prime}=37.5 \mathrm{~mm}\right)$. The failure angle $\beta$ is

186 determined from the conical wedge formed during the test under the steel punches

187 according to Eq. (3), where $\varphi$ is the internal friction angle of the material (this angle

188 determines the cracking surface of the conical wedge as shown in Figure 2). The actual

189 length of the conical wedge $(l)$, and the consequent angle $\beta$, was measured for several 190 specimens tested after the thermal treatment up to $25^{\circ} \mathrm{C}, 200^{\circ} \mathrm{C}, 400^{\circ} \mathrm{C}$ and $600^{\circ} \mathrm{C}$ (see 191 item 3.2).

$$
l=\frac{d^{\prime}}{2} \cdot \tan \varphi
$$

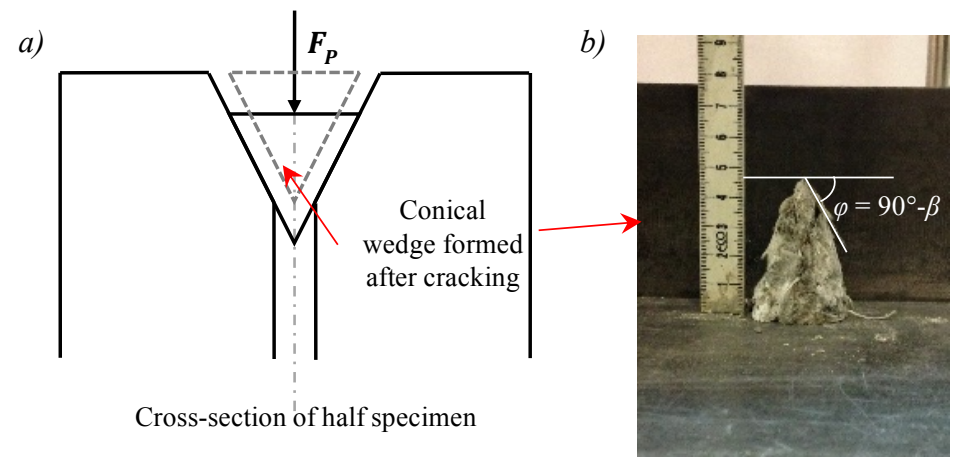

193 (1.5 column fitting image; preference for color: online only)

194 Figure 2 - (a) Cross-section of half specimen after cracking and formation of the cone and

195 (b) conical wedge from specimen with thermal treatment up to $200^{\circ} \mathrm{C}$. 
196 The kinetic friction coefficient $\left(\mu_{k}\right)$ of the concrete is a parameter that has not been studied

197 in detail in the literature. In fact, the information available refers to the static friction

198 coefficient of concrete $\left(\mu_{s}\right)$, however it is known that $\mu_{k}$ should be smaller than $\mu_{s}$ for the

199 same surface. This is particularly true for the case of the Barcelona test since two concrete

200 surfaces are subjected to a significant relative displacement. In the absence of reliable

201 values of $\mu_{k}$, a reasonable approximation is 0.7 , which corresponds to the limit value between smooth and rough surfaces defined in the Model Code 2010 [18].

In order to assess the post-heating tensile behavior of the studied MSFRC, BCN specimens were heated in an electric oven (Inforgel Company) up to the following temperatures: $200^{\circ} \mathrm{C}, 400^{\circ} \mathrm{C}$, and $600^{\circ} \mathrm{C}$. Experiments on control specimens (unheated MSFRCs, just cured at $40^{\circ} \mathrm{C}$ ) were also carried out. The BCN specimens were covered by steel mesh in order to avoid damage to the furnace in case of explosive spalling. The heating rate was maintained in $16^{\circ} \mathrm{C} / \mathrm{min}$ (largest value allowed by the used furnace).

Differently from a real tunnel fire (single-face heating), inside the oven, heating occurs in the entire outer surface of the specimens. Seeking to stabilize the specimens at the

211 studied target temperatures, a sustained thermal load of 60 min was employed. The choice

212 for this exposure time is based on data about duration of fires (along the last 5 decades) reported by the International Tunneling Association (ITA) [19]. After the heating process,

214 the cylindrical specimens destined to the residual BCN tests were cooled down naturally

215 within the furnace until reach the room temperature. Such process was carried out to

216 prevent large thermal gradients capable of cracking the concrete composite. At the end of

217 the test, the following parameters were determined: First crack tensile strength $\left(\sigma_{\mathrm{cr}}\right)$, 218 residual tensile strengths for strains of $0.2 \%\left(\sigma_{0,2} \%\right)$ and $0.4 \%\left(\sigma_{0,4 \%}\right)$, and energy density 219 for strains of $0.2 \%\left(\mathrm{~A}_{0,2 \%}\right)$ and $0.4 \%\left(\mathrm{~A}_{0,4 \%}\right)$. 
221 The compressive strength $\left(f_{c}\right)$ and elastic modulus $\left(E_{c}\right)$ of the produced MSFRC were carried out in $75 \times 150 \mathrm{~mm}$ (diameter $\mathrm{x}$ height) cylinders using three specimens for each target temperature (see item 2.1). As well as in the BCN test, compressive strength assessment was performed not only at room temperature $\left(25^{\circ} \mathrm{C}\right)$ but also in specimens heated up to $200^{\circ} \mathrm{C}, 400^{\circ} \mathrm{C}$ and $600^{\circ} \mathrm{C}$. The compressive load was applied at a rate of

$2260.1 \mathrm{~mm} / \mathrm{min}$ by using a Shimadzu universal testing machine (model UH-F1000kN) with a computer-controlled hydraulic servo system. The composite axial strain was determined by the average of two displacement transducers attached around the specimen. The elastic modulus was obtained on the elastic range of the stress-strain curves located between 0.5

$230 \mathrm{MPa}$ and $0.3 \mathrm{f}_{\mathrm{c}}$.

\subsubsection{Direct tensile tests of macro-synthetic fibers}

232 Monotonic tension tests were performed in single macro-synthetic fibers in order to

233 evaluate their mechanical properties at room temperature, as well as, to assess the effect

234 of temperature on the fibers residual tensile properties. In that sense, fibers with $10 \mathrm{~mm}$

235 of gage length were tensioned in a horizontal electromechanical testing machine (MTS, 236 model Tytron 250) coupled to a $50 \mathrm{~N}$ load cell and a $5 \mu \mathrm{m}$ precision extensometer. Load 237 and displacement measurements were recorder at a rate of $4 \mathrm{~Hz}$. The test methodology 238 adopted here follows the study proposed by Estrada et al. [21] for the evaluation of fibers 239 already cut in the length of use. The results obtained in such condition may differ in terms 240 of strength and, in particular, modulus of elasticity, with relation to the tensile test 241 performed on original yarns usually employed by the producers of fibers. However, it 242 allows to evaluate the fiber performance as a function of temperature, which is one of the 243 key objectives in the present study. A displacement rate of $0.4 \mathrm{~mm}$ was adopted to all 244 direct tensile test. For each studied temperatures, 6 macro-synthetic fibers were tested. 245 Each single fiber was glued to a paper template in order to allow a perfect alignment with 
246 the machine grips. The ultimate tensile strength $\left(\sigma_{\mathrm{urs}}\right)$ of fibers was calculated dividing

247 the maximum load value by the fiber cross-sectional area obtained in the fracture site.

248 The fracture planes of the fibers were analyzed through a Scanning Electron Microscope

249 (SEM) Hitachi TM3000 and subsequently treated using the software ImageJ. The elastic

250 modulus was calculated in the ascending branch of the stress-strain curves located

251 between $10 \%$ and $40 \%$ of $\sigma_{\text {urs. }}$. The obtained data were also analyzed through analysis of 252 variances (ANOVA).

\subsubsection{Materials characterization}

\subsubsection{Matrix and fiber-matrix interfaces (SEM, TG, DSC)}

255 The fiber-matrix interfaces of the thermal treated MSFRC $\left(25^{\circ} \mathrm{C}, 200^{\circ} \mathrm{C}, 400^{\circ} \mathrm{C}\right.$ and $600^{\circ} \mathrm{C}$ ) were investigated in three different zones along the central axis of the BCN specimens: 0 (Zone 1), 3.75 (Zone 2) and 7.5cm (Zone 3) (see Figure 1). The Scanning

258 Electron Microscope (SEM) was operated using $25 \mathrm{kV}$ of acceleration tension and $30 \mathrm{~mm}$ of working distance. The samples (extracted from the fractured $\mathrm{BCN}$ specimens) were attached to a circular plate-shaped stage (diam: $20 \mathrm{~mm}$ ) and analyzed without any coating. Thermo Gravimetric (TG) analyses were carried out at the Zone 3, using pulverized sample material ( $\sim 40 \mathrm{mg})$ obtained from the already tested BCN specimens. To extract the powder a rotary impact drill was employed. The samples were heated in platinum sample holders from $35^{\circ} \mathrm{C}$ to $1000^{\circ} \mathrm{C}$ in a TA Instruments, SDT Q600 model TGA/DTA/DSC simultaneous apparatus at a heating rate of $10^{\circ} \mathrm{C} \min ^{-1}$ and using 100 $\mathrm{mL} / \mathrm{min}$ of nitrogen flow. An isothermal step of $60 \mathrm{~min}$ at $35^{\circ} \mathrm{C}$ was carried out before

267 performing TG analysis. Such process was conducted in order to eliminate the residual 268 non-bonded free water present in the powder material. X-ray diffraction (XRD) analyses were also carried out in the Zone 3 of the thermal treated BCN specimens. The samples used in the XRD analyses were also obtained from the powder extracted by the impact 
drill. Operating conditions for qualitative analysis of the Bruker D8 advance instrument were set to $40 \mathrm{kV}$ and $40 \mathrm{~mA}$ using $\mathrm{CuK} \alpha_{1,2}$ radiation. XRD profiles were recorded in an angular range $2 \theta$ of $13^{\circ}$ to $60^{\circ}$ with increments of $0.02^{\circ}$. The choice of qualitative analyzes was based on the intense quartz peaks (aggregate phase) present in the MSFRC diffractograms, as well as the difficulty of maintaining the material proportions (i.e: aggregates and paste) in the collected samples. Since the intense quartz peaks present on the diffractograms of the MSFRC, can hinder the identification of compounds with minor peaks, TG and XRD analysis were also carried out in samples prepared from the cement and from the paste.

\subsubsection{Macro-synthetic fiber (crystallinity degree)}

281 In general, polymers are composed by amorphous phases. However, as the fibers are

282 produced by extrusion and stretching, they could present a higher level of crystallinity.

283 Their mechanical properties, directly depends on the crystalline phase which, in turn, is 284 related with the packaging of the chains in an organized manner [20,21]. Once the crystalline phase is affected by thermal loads, an investigation on the degree of crystallinity of the employed macro-synthetic fibers (polypropylene) was developed. The

287 goal, therefore, was to correlate the losses of the crystallinity of fibers with the decrease

288 of the MSFRCs tensile performance when exposed to heat. The crystallinity percentage was determined by using the area under the peak relative to the melting of the crystalline

290 phase obtained by DSC, as well as shown in the Equation 4.

$291 \% X_{c}=\frac{\Delta H_{\text {sample }}^{0}}{\Delta H_{\text {standart }}^{0}} \times 100$

292 Where: 
$\Delta H_{\text {sample }}^{0}=$ sample melting enthalpy

$\Delta H_{\text {standart }}^{0}=$ enthalpy of the reference sample $(209 \mathrm{~J} / \mathrm{g})[22]$

296 TG/DSC analyses were carried using fragments of fibers $(10 \mathrm{mg})$ extracted manually from

297 the tested BCN specimens. The fiber samples were heated in platinum sample holders 298 from $25^{\circ} \mathrm{C}$ to $700^{\circ} \mathrm{C}$ in a TA Instruments (STA6000) model Perkin Elmer TGA/DSC

299 simultaneous apparatus at a heating rate of $20^{\circ} \mathrm{C} \mathrm{min}^{-1}$ and using $20 \mathrm{~mL} / \mathrm{min}$ of nitrogen

300 flow. An isothermal step of $1 \mathrm{~min}$ at $25^{\circ} \mathrm{C}$ was carried out before performing DSC

301 analysis. To ensure no cement and aggregate contamination, the samples were soaked in

3021 mol.L $\mathrm{L}^{-1}$ hydrochloric acid solution $\left(\right.$ at $\left.40^{\circ} \mathrm{C}\right)$ and stirred for about 30 minutes.

\section{3. Results and discussion}

304 In this item, the mechanical performance and microstructural features of the MSFRC,

305 before and after exposure to the target temperatures, $\left(200^{\circ} \mathrm{C}, 400^{\circ} \mathrm{C}\right.$ and $\left.600^{\circ} \mathrm{C}\right)$, were

306 carefully examined. The obtained data (e.g.: tensile and compression strength, elastic

307 modulus, etc) were treated through analysis of variances (ANOVA). As shown in Figure

3083 , no explosive spalling was observed in the composites after the heating program. From

$309200^{\circ} \mathrm{C}$ and above, however, all specimens presented thermal cracking and fiber 310 detachment.
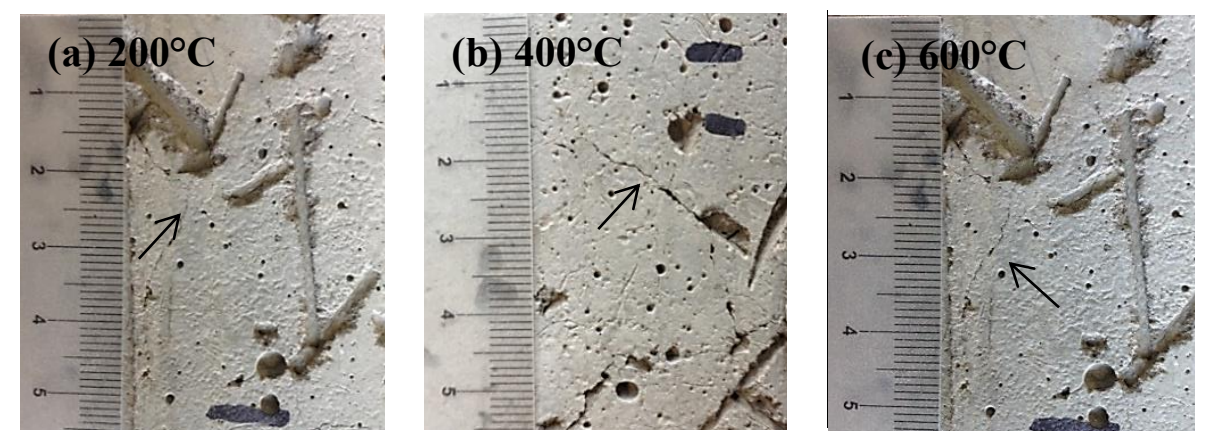

311 (1.5 column fitting image; preference for color: online only) 
312 Figure 3 - Surface degradation observed on the BCN specimens after thermal treatment

313 up to (a) $200^{\circ} \mathrm{C}$, (b) $400^{\circ} \mathrm{C}$ and (c) $600^{\circ} \mathrm{C}$.

$314 \quad 3.1 \quad$ Effect of temperature on the MSFRC compressive strength and elastic 315 modulus

316 Figure 4 presents the variation of compressive strength and elastic modulus evolution of

317 the MSFRC (at an age of 28 days) for each tested specific target temperature $\left(25^{\circ} \mathrm{C}\right.$,

$318200^{\circ} \mathrm{C}, 400^{\circ} \mathrm{C}$ and $600^{\circ} \mathrm{C}$ ). The average results can be found on Table 4 . The specimens

319 tested at room temperature presented an average compressive strength of $58.2 \mathrm{MPa}$ as

320 well as an elastic modulus of $28.1 \mathrm{GPa}$.

321 The residual compressive strength values obtained at $200^{\circ} \mathrm{C}, 400^{\circ} \mathrm{C}$ and $600^{\circ} \mathrm{C}$, shown to

322 be, respectively, $9.2 \%, 34.6 \%, 64.9 \%$ lower than the value reached at room temperature.

323 The losses in the elastic modulus were still greater for the same target temperatures,

$32431.0 \%, 87.6 \%$ and $96.6 \%$, respectively. As can be seen in Figure 4b, the most pronounced

325 decrease in the modulus of elasticity occurs between $200^{\circ} \mathrm{C}$ and $400^{\circ} \mathrm{C}$ and represents a

326 reduction of $82.1 \%$. This is in line with other studies that also identify the range of $200^{\circ} \mathrm{C}$ -

$327400^{\circ} \mathrm{C}$ as the one presenting the main difference between the material responses in most

328 cases $[11,13]$.

329 This continuous loss of strength is given by different processes, among which can be

330 highlighted, the dehydration of hydrated products present in the concrete matrix, the

331 mismatch between the aggregate and the cement paste thermal expansion, the increases

332 in the matrix and aggregate porosity and the degradation of synthetic fibers. These

333 processes will be further addressed in the item 3.4 and correlated with microstructural

334 analyses. 

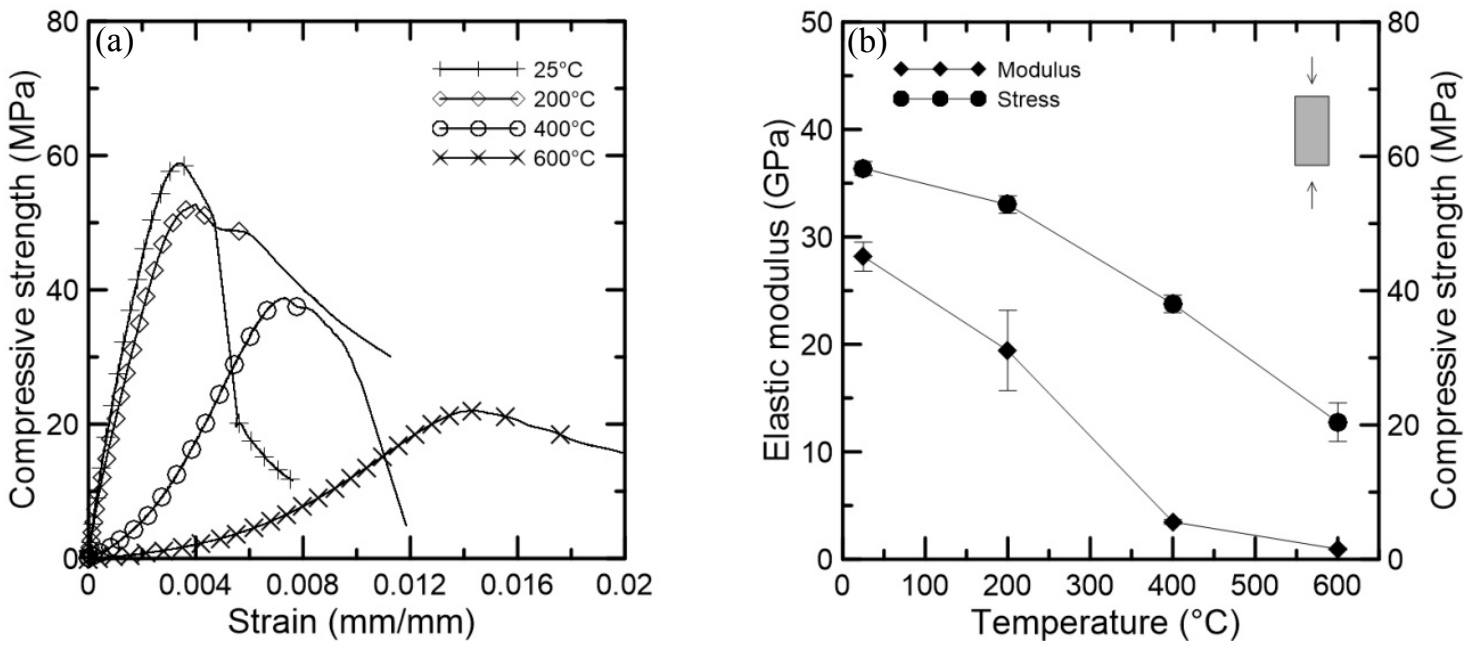

336 (1.5 column fitting image; grayscale)

337 Figure 4 - (a) Typical stress-strain curves obtained for the MSFRC under compression

338 before and after heat treatment; (b) Average loss in compressive strength and elastic

339 modulus obtained for each studied temperature.

340

\begin{tabular}{cccccc}
\hline \multirow{2}{*}{$\begin{array}{c}\text { Target } \\
\text { temperature }\end{array}$} & \multicolumn{2}{c}{ Compressive strength } & \multicolumn{3}{c}{ Tensile strength (BCN) } \\
\cline { 2 - 6 } & $\begin{array}{c}\mathrm{f}_{\mathrm{c}} \\
(\mathrm{MPa})\end{array}$ & $\begin{array}{c}\mathrm{E}_{\mathrm{c}} \\
(\mathrm{GPa})\end{array}$ & $\begin{array}{c}\sigma_{\mathrm{cr}} \\
(\mathrm{MPa})\end{array}$ & $\begin{array}{c}\sigma_{0.2 \%} \\
(\mathrm{MPa})\end{array}$ & $\begin{array}{c}\sigma_{0.4 \%} \\
(\mathrm{MPa})\end{array}$ \\
\hline \multirow{2}{*}{$25^{\circ} \mathrm{C}^{*}$} & 58.20 & 28.17 & 4.10 & 2.42 & 1.90 \\
& $(1.03)$ & $(1.35)$ & $(0.16)$ & $(0.15)$ & $(0.13)$ \\
$200^{\circ} \mathrm{C}$ & 52.82 & 19.43 & 3.56 & 2.40 & 1.87 \\
& $(1.30)$ & $(3.73)$ & $(0.15)$ & $(0.15)$ & $(0.11)$ \\
$400^{\circ} \mathrm{C}$ & 38.02 & 3.48 & 3.28 & 1.11 & - \\
& $(1.31)$ & $(0.21)$ & $(0.17)$ & $(0.17)$ & \\
$600^{\circ} \mathrm{C}$ & 20.42 & 0.95 & 1.53 & 1.31 & - \\
\hline
\end{tabular}

341

*Room temperature

343 Table 4 - Post-heating mechanical strength obtained for the MSFRC. Standard deviation

344 values are presented in parentheses.

\subsection{Effect of temperature on the MSFRC post-heating tensile strength}

347 As reported in the item 2.2.1 the length of the conical wedge $(l)$ was measured for all 348 target temperatures in order to obtain the angle $\beta$, necessary to tensile strength 
349 determination. The $\beta$ values obtained for $25^{\circ} \mathrm{C}, 200^{\circ} \mathrm{C}, 400^{\circ} \mathrm{C}$ and $600^{\circ}$ were, 350 respectively, $21^{\circ}, 22^{\circ}, 18^{\circ}$ and $18^{\circ}$. Given the difficulty associated with the extraction of 351 a representative number of cones from the BCN specimens, especially in the case of well 352 degraded concretes (heated up to $400^{\circ} \mathrm{C}$ and above), the authors chose to employ an 353 average angle $\beta$ of $21^{\circ}$ for the calculation (common to all temperatures). In all studied 354 temperatures, the tensile behavior of the MSFRCs was expressed in the form of stress 355 versus strain curves (see Figure 5). All composites presented strain softening behavior 356 when submitted to the BCN test, even those tested at room temperature. Through Figure 3575 is possible to percept that the MSFRC crack strength $\left(\sigma_{\mathrm{cr}}\right)$ decreases gradually with 358 increasing temperature, being the referred decrease more pronounced between 400 and $359600^{\circ} \mathrm{C}$. Figure 6 a presents the average values $\sigma_{\text {cr }}$ for all MSFRCs. The average first crack 360 strength values obtained for $200^{\circ} \mathrm{C}, 400^{\circ} \mathrm{C}$ and $600^{\circ} \mathrm{C}$ were, respectively, $13.2 \%, 20 \%$ 361 and $62.5 \%$ lower than that obtained for $25^{\circ} \mathrm{C}$. 

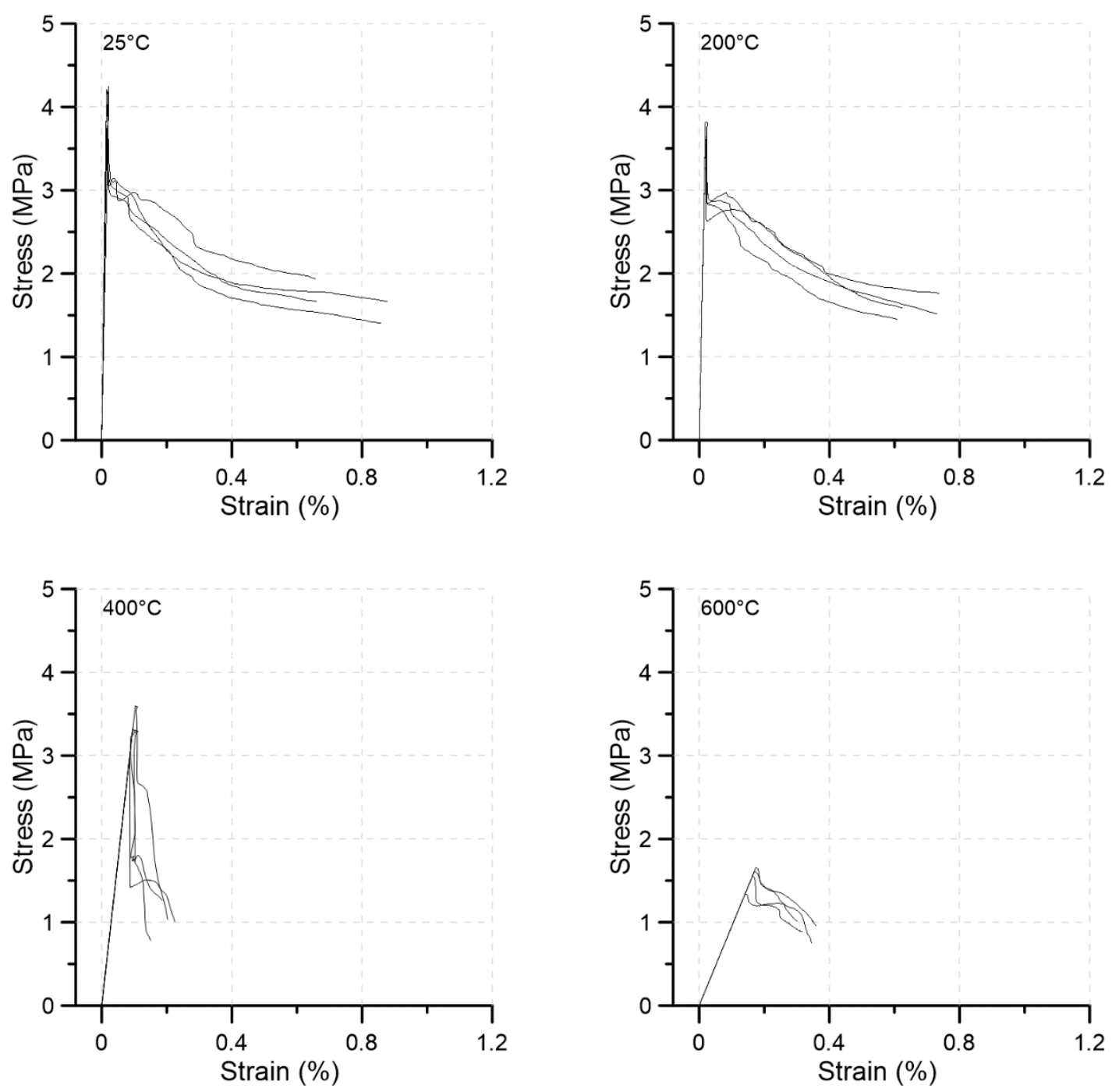

363 (1.5 column fitting image; grayscale)

364 Figure 5 - Stress-strain curves obtained from the results of the Barcelona test for the

365 MSFRC specimens submitted to different temperatures.

367 The post-cracking response of the MSFRCs varies significantly depending on the

368 temperature. According to the curves in Figure 5, the MSFRC exposed up to $200^{\circ} \mathrm{C}$

369 maintain similar values of the residual strength and overall ductility when compared to

370 the MSFRC at room temperature. However, from $400^{\circ} \mathrm{C}$ upwards, the bearing capacity

371 of the material is significantly reduced (see item 3.4). Figure 6a shows the residual

372 strengths of all MSFRCs, associated to strain levels of $0.2 \%$ and $0.4 \%$. 

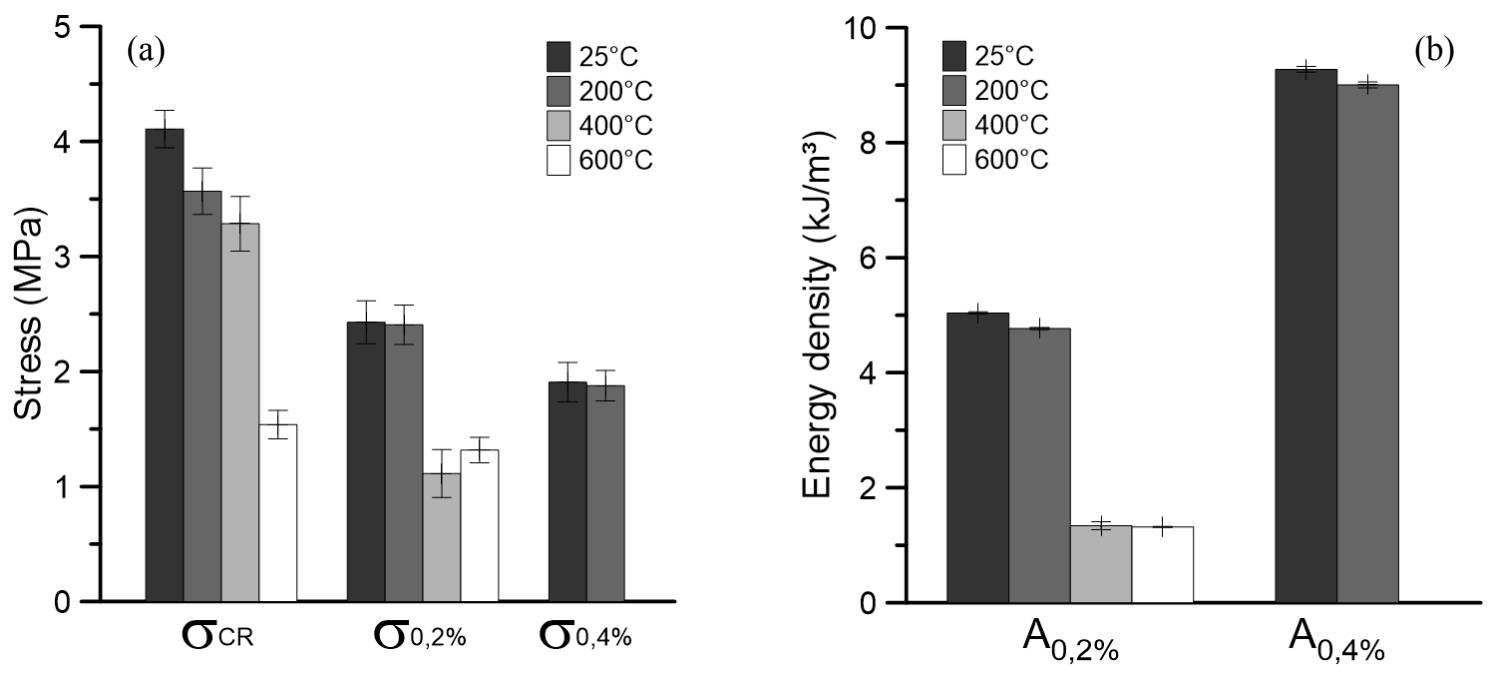

374 (1.5 column fitting image; grayscale)

375 Figure 6 - (a) Average first crack tensile strength and residual strengths for strains of

$376 \quad 0.2 \%$ and $0.4 \%$, and (b) energy consumption density for strains of $0.2 \%$ and $0.4 \%$.

377

378 The average $\sigma_{0.2 \%}$ obtained for $200^{\circ} \mathrm{C}, 400^{\circ} \mathrm{C}$ and $600^{\circ} \mathrm{C}$ were, respectively, $0.9 \%, 54.2 \%$

379 and $45.7 \%$ lower than that obtained for $25^{\circ} \mathrm{C}$. Such outcome may be explained by the

380 decomposition process suffered by the fibers when subjected to high temperatures, which

381 already starts at about $\sim 300^{\circ} \mathrm{C}$ (Figure 7).

382

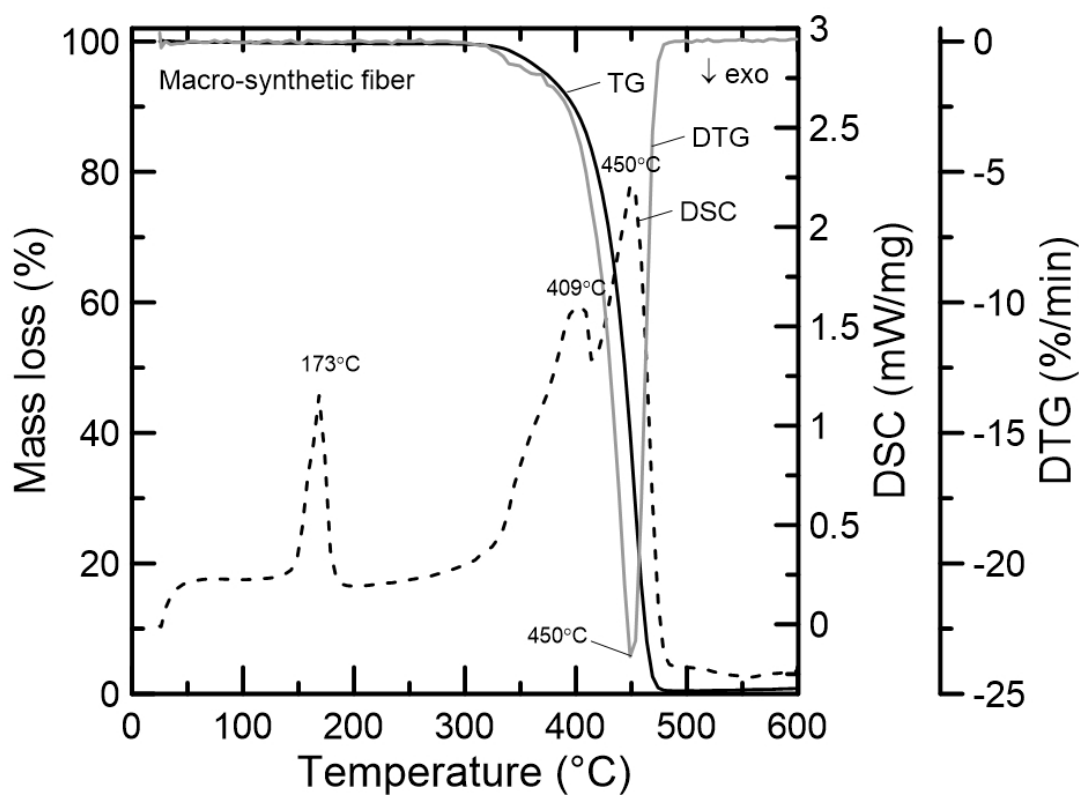


385 Figure 7 - DSC, TG, and DTG of the macro-synthetic fibers.

386 The average $\sigma_{0.4 \%}$ obtained for $200^{\circ} \mathrm{C}$ was only $1.6 \%$ lower than that measured for $25^{\circ} \mathrm{C}$,

387 thus indicating that the fibers exposed to such temperature are still capable of providing

388 ductility to the composite. The MSFRCs specimens exposed to $400^{\circ} \mathrm{C}$ and $600^{\circ} \mathrm{C}$ did not 389 reach that level of strain during the test (see Figure 5).

390 Figure $6 \mathrm{~b}$ presents the values of energy consumption density (in $\mathrm{kJ} / \mathrm{m}^{3}$ ) associated to the 391 aforementioned strain levels. This parameter is calculated as the average area below the 392 stress-strain curves of all specimens. It has been used in previous studies $[23,24]$ to assess

393 the overall post-cracking response of fiber reinforced concrete instead of only using specific values of residual strength. The results also confirm that the critical temperature which alters the response of the MSFRC is $400^{\circ} \mathrm{C}$. The average energy consumption densities at a value of strain of $0.2 \%$ for $200^{\circ} \mathrm{C}, 400^{\circ} \mathrm{C}$ and $600^{\circ} \mathrm{C}$ were, respectively, $5.4 \%, 73.4 \%$ and $89.9 \%$ lower than that obtained for $25^{\circ} \mathrm{C}$. The same analysis for a strain of $0.4 \%$ is only possible for the MSFRC exposed to $200^{\circ} \mathrm{C}$ and its value is only $2.9 \%$ lower than that corresponding to the reference temperature $\left(25^{\circ} \mathrm{C}\right)$. As well as the compression results, the effect of temperature on the MSFRCs will be further addressed in the item 3.4, in which the mechanical results are linked to the microstructural analyses.

3.3 Effect of temperature on the tensile strength and elastic modulus of the macro-synthetic fibers.

405 Based on the procedure described in the item 2.2.3, the residual tensile strength and elastic 406 modulus of the studied macro-synthetic fibers, were determined for $25^{\circ} \mathrm{C}, 75^{\circ} \mathrm{C}$ and $407100^{\circ} \mathrm{C}$. Regarding tensile strength, the average values obtained for the aforementioned 408 temperatures were respectively $275 \mathrm{MPa}, 289 \mathrm{MPa}$ and $325 \mathrm{MPa}$. With relation to the 
409 elastic modulus, the obtained average values were 2.6 GPa, 2.6 GPa and 2.9 GPa for the

410 same temperatures. For temperatures above $100^{\circ} \mathrm{C}$, longitudinal shrinkage was observed

411 along the fiber length, impairing the test from the execution point of view. As reported

412 before, six fibers were tested for each studied temperature. The obtained results showed

413 that the low temperatures employed for the residual tensile tests (below the melting point)

414 were not capable to alter the fiber mechanical properties (see Figure 8). Such uniformity

415 was clearly noticed comparing the strength and elastic modulus of all fibers in statistical

416 tests, in which the p-values were higher than 0.05 (ANOVA).

417

418

419

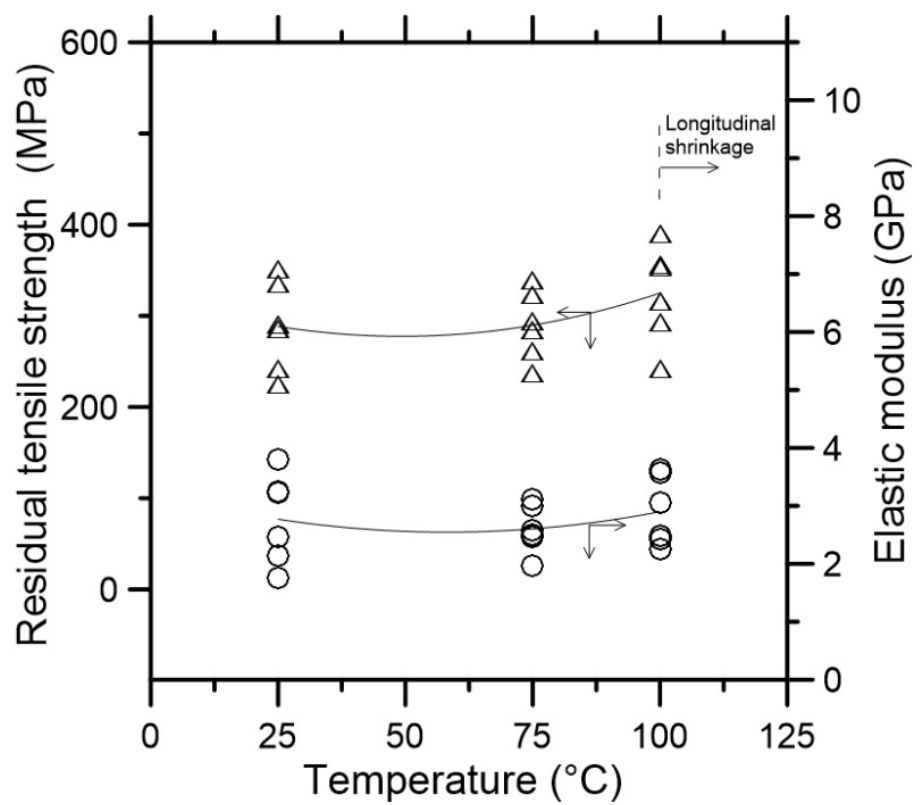

420 (Single column fitting image; grayscale)

421 Figure 8 - Effect of temperature on the tensile strength (a) and elastic modulus (b) of the 422 studied macro-synthetic fibers.

423

$424 \quad 3.4 \quad$ Micro-structural characterization and mechanical properties 
425 Figure 9 presents the TG and DTG curves obtained for the MSFRC, in all studied target 426 temperatures. These curves refer to the central portion of concrete located at Zone 3

427 ( $7.5 \mathrm{~cm}$ from the top). The TG and DTG curves are plotted starting from the end of the 428 aforementioned isothermal stage at $35^{\circ} \mathrm{C}$ (see item 2.2.4.1). Initially, in the reference 429 sample $\left(25^{\circ} \mathrm{C} \_\right.$Zone 3$)$ the imposed heating regime tends to drive out the free water 430 (present in the matrix) and accelerate its diffusion through the hardened paste. In parallel, 431 calcium silicate hydrate $(\mathrm{CSH})$ and ettringite (AFt) starts to dehydrate increasing the 432 porosity of cement paste while reducing the strength of the whole composite. Given the 433 overlapping of the DTG peaks, the decomposition process of such compounds cannot be 434 clearly distinguished.

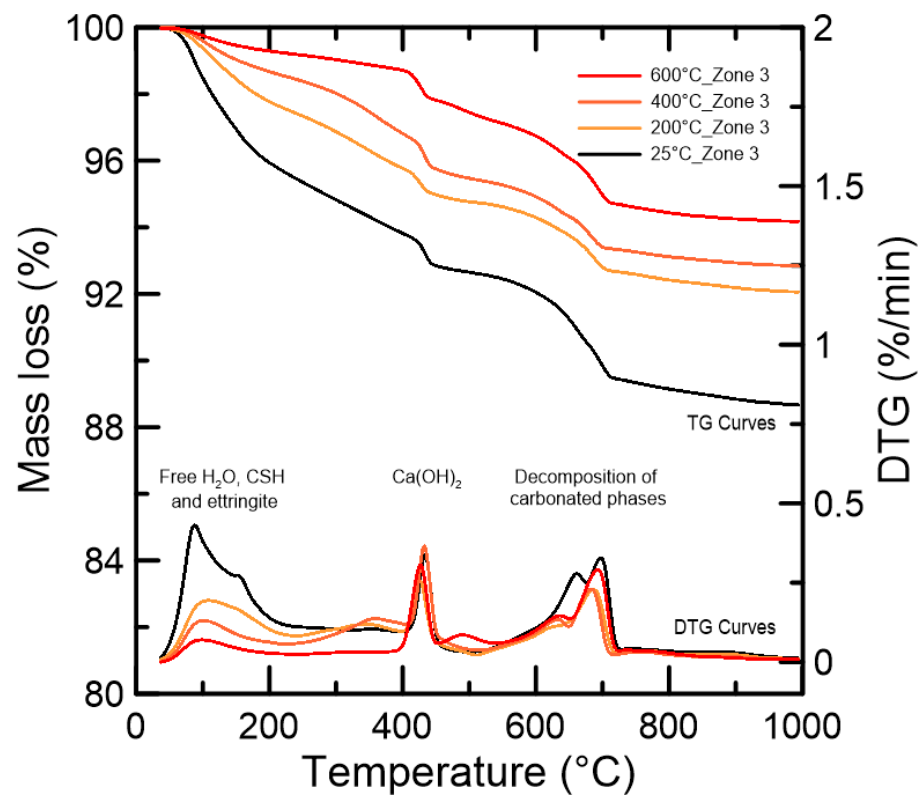

(Single column fitting image; preference for color: online only)

437 Figure 9 - TG and DTG curves of powder material extracted from the central axis of the 438 MSFRC at room temperature and after heating process up to $200^{\circ} \mathrm{C}, 400^{\circ} \mathrm{C}$ and $600^{\circ} \mathrm{C}$.

440 The presence of the CSH and AFt was detected by XRD in the diffractograms performed 441 on the MSFRC $\left(25^{\circ} \mathrm{C} \_\right.$Zone 3$)$ and in the hydrated cement paste (Figure 10$)$. $\mathrm{CSH}$ is 
442 formed during the hydration of alite $\left(\mathrm{C}_{3} \mathrm{~S}\right)$ and belite $\left(\mathrm{C}_{2} \mathrm{~S}\right)$ phases. Ettringite, however,

443 is formed from the phases commonly called as aluminate $\left(\mathrm{C}_{3} \mathrm{~A}\right)$ and gypsum $\left(\mathrm{CS}^{\mathrm{S}} \mathrm{H}_{2}\right)$,

444 consuming high amount of water [25]. All of these phases (alite, belite, aluminate and

445 gypsum) were detected in the cement powder through the XRD, together with the ferrite

446 phase $\left(\mathrm{C}_{4} \mathrm{AF}\right)$ (see Figure 10).

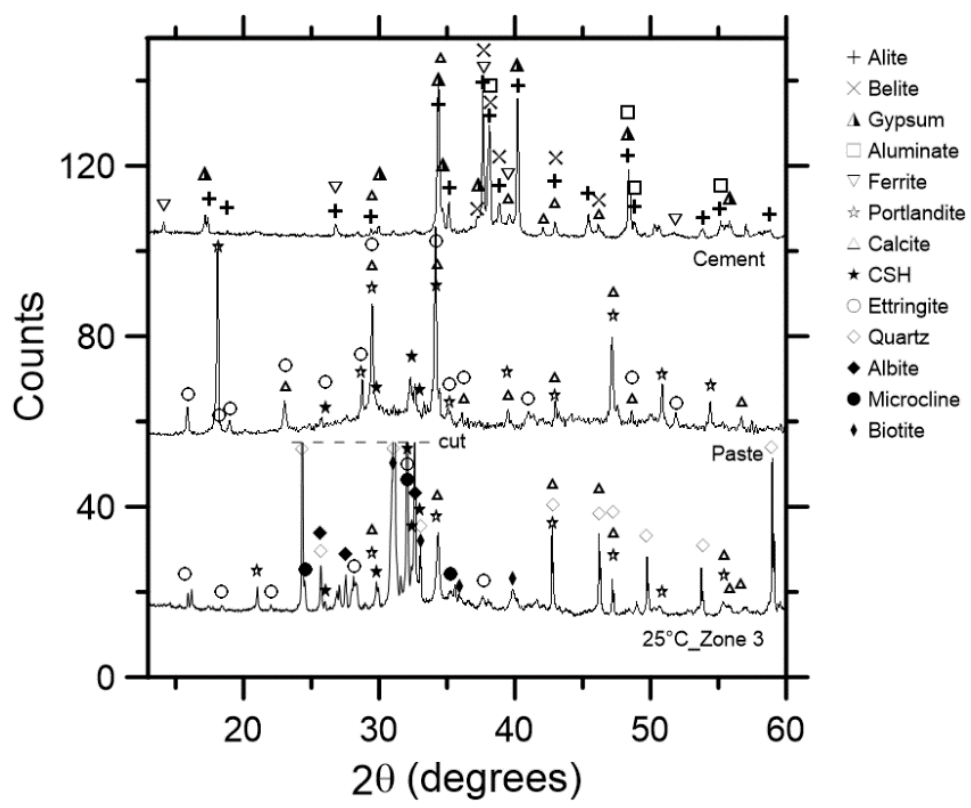

448 (Single column fitting image; grayscale)

449 Figure 10 - XRD patterns obtained for the cement, paste and for the MSFRC $\left(25^{\circ} \mathrm{C}\right.$ Z Zone $4503)$.

451

452 The first step of dehydration, corresponding to CSH and AFt present a long descending 453 branch which extends to about $500^{\circ} \mathrm{C}$ (Figure 9). Other degradation steps are still 454 observable on the TG curve of the reference sample $\left(25^{\circ} \mathrm{C} \_\right.$Zone 3$)$. The second major 455 step, between 400 and $500^{\circ} \mathrm{C}$, refers to the dehydration of the calcium hydroxide $456\left(\mathrm{Ca}(\mathrm{OH})_{2}\right)$ [25]. For temperatures above $500^{\circ} \mathrm{C}$, it is possible to observe the 457 decomposition of the carbonated phases identified by XRD as calcite $\left(\mathrm{CaCO}_{3}\right)$. 
458 In the Zone 3 of the MSFRC heated up to $200^{\circ} \mathrm{C}$, it is possible to percept that only the

$459 \mathrm{CSH}$ and AFt were partially decomposed (see first DTG peak on Figure 9). Greater

460 dehydration does not occur because the imposed heating regime is not capable, or long

461 enough, to take the core (Zone 3) up to $200^{\circ} \mathrm{C}$. Thus, great part of the microstructure is

462 preserved and so the matrix compressive and tensile strength (see Table 4). As the internal

463 temperature increase, thermal expansion of the aggregates give rise to internal stresses

464 within the composite. Such stress, resulted in micro-cracks, which shown to be visible to

465 naked eye in the studied composites (Figure 3). In the MSFRC heated up to $200^{\circ} \mathrm{C}$, no

466 fiber degradation was observed. However, the fibers located close to the specimen surface

467 (Zone 1), presented longitudinal shrinkage. According to Diaz and Youngblood [26],

468 thermal shrinkage is a particular characteristic of highly aligned polypropylene

469 reinforcements, in which values of shrinkage of up to $6 \%$ may be expected, depending on

470 the applied restriction and temperature conditions. However, as reported by the same

471 authors, what actually occurs with rising temperature is a joint effect of thermal shrinkage,

472 thermal expansion and creep occurring at the same time in the polymer. SEM images

473 were used to investigate the inner portions of the composite, looking for alterations on

474 the fiber reinforcement. The micrographs, however, did not show any difference between

475 the reinforcement at $25^{\circ} \mathrm{C}$ and $200^{\circ} \mathrm{C}$ just below the surface. The thermal field established

476 in a concrete cylinder exposed to elevated temperatures is time-dependent and, for a short

477 exposure time (case of this study), the temperature decreases significantly along the radial

478 direction. In addition, temperature histories of points inside the furnace and on the faces

479 of the heated specimen may present great differences [27]. Studies performed by Shaikh

480 and Vimonsatit [28] where thermocouples were embedded in cylinders exposed to

481 elevated temperatures (heating rate: $8^{\circ} \mathrm{C} / \mathrm{min}$ ) revealed that even after $1 \mathrm{~h}$ at $200^{\circ} \mathrm{C}$ the

482 central portion of the concrete specimens (distant $5 \mathrm{~cm}$ from the surface) does not reach 
more than $120^{\circ} \mathrm{C}$. Such results allow us to presume that for larger specimens (case of

484 BCN specimens) heated up to same temperature $\left(200^{\circ} \mathrm{C}\right)$, the thermal gradient till the center is even greater. This may explain why the mechanical behavior at $200^{\circ} \mathrm{C}$ is so close to that at $25^{\circ} \mathrm{C}$ (under compression and tension) and why the macro reinforcement

487 remains intact as well as part of the CSH and Aft. Such idea also agree well with the 488 mechanical results reported in the item 2.2.3 which prove that there is no residual strength decrease in the macro reinforcement up to $100^{\circ} \mathrm{C}$.

490 Observing the thermogravimetric analysis for the Zone 3 of the MSFRC heated up to $400^{\circ} \mathrm{C}$, it is possible to percept a more intense decomposition of $\mathrm{CSH}$ and $\mathrm{AFt}$ up to about $250^{\circ} \mathrm{C}$. The rest of the curve (above $250^{\circ} \mathrm{C}$ ), as well as in the MSFRC heated up to $200^{\circ} \mathrm{C}$, remained practically unchanged. As a result of a more pronounced decomposition of hydrated phases (especially CSH), a loss of $34.6 \%$ was observed in the compressive strength (see item 3.1). Regarding the tensile performance of the MSFRC, especially in the post cracking region, great decreases were observed for $400^{\circ} \mathrm{C}$ and above (Table 4).

497 Such results are directly related to the matrix thermal degradation, but also to the changes 498 in the reinforcement strength (i.e. in the polymer crystallinity). Figure 11 shows 499 micrographs of the interfaces between fibers and matrix at room temperature (Zone 3), 500 and after heating process up to $400^{\circ} \mathrm{C}$ : (Zone 1, Zone 2 and Zone 3 ). At room temperature 501 (Figure 11a), both micro and macro-fibers appear intact in the fractured MSFRC. The 502 circular and elliptical hollows observed for $400^{\circ} \mathrm{C}$ (Zone 1) indicate clearly that, the 503 temperature in this site was capable to fully decompose both polymeric fibers (see Figure $50411 b)$.
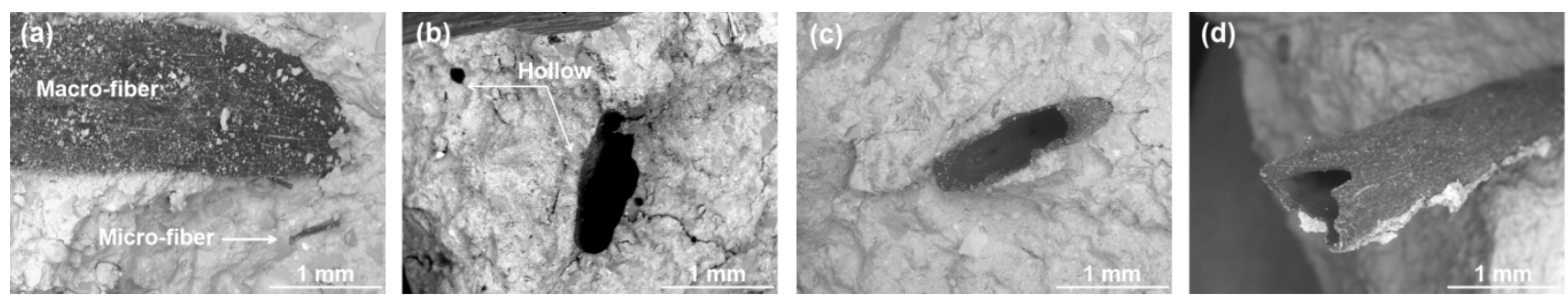
507 Figure 11 - Interface between the matrix and the macro-synthetic fibers (a) at room

508 temperature and after heating process up to $400^{\circ} \mathrm{C}$ : (b) Zone 1, (c) Zone 2 and (d) Zone 5093.

510 The absence of fibers was observed up to around $1.6 \mathrm{~cm}$ from the border of the specimen,

511 which means that the macro reinforcement was fully compromised in approximately $52 \%$

512 of the specimen volume, while the rest retain part of its functionality. This phenomenon

513 was also observed in concrete composites containing macro-synthetic fibers studied by

514 Choumanidis et al. [14] where BCN specimens were submitted to a low heating ramp

$515\left(2^{\circ} \mathrm{C} / \mathrm{min}\right)$ up to $280^{\circ} \mathrm{C}$.

516 The micrographs performed on the MSFRC inner portions (i.e.: Zones 2 and 3), however,

517 shown that, instead of hollows, "polymeric tubes" were formed into the fiber beds at $518400^{\circ} \mathrm{C}$ (Figure 11c-d). Such distinct shape, results from different process associated to the 519 heating regime. First, the polymer expand [29] inside the porous matrix when the 520 temperature get closer to the polymer $\mathrm{T}_{\mathrm{m}}$. Once melted, the portion of polymer which 521 remains in the "fiber bed" (adhered to surrounding matrix) experiences a non-isothermal recrystallization process using the walls as areas of nucleation and growing of crystals

523 (during the cooling process). This will only occur, however, if the temperature is not able 524 to fully decompose the polymer. Observing the micrographs shown in the Figure 11c-d, 525 it is well probable that at least partial polymer decomposition occurred in the Zones 2 and 5263 of the MSFRC heated up to $400^{\circ} \mathrm{C}$.

527 As well as the concrete, the polymer loses its strength with increasing temperature up to $528400^{\circ} \mathrm{C}$. Figure 12 shows the comparison of the melting enthalpy generated by unheated 529 fibers $\left(25^{\circ} \mathrm{C}\right)$ and fibers extracted from Zone 3 of the specimens heated up to $400^{\circ} \mathrm{C}$. 530 Dividing the measured enthalpies by the enthalpy of the reference sample (209J/g) [22], 
531 crystallinity degrees of $46.7 \%$ and $35.1 \%$ were observed for the fiber extracted from the 532 reference MSFRC $\left(25^{\circ} \mathrm{C}\right.$-Zone 3$)$ and that heated up to $400^{\circ} \mathrm{C}$ (Zone 3), respectively.

533 This drop on the crystallinity reduces the reinforcement strength [30], which in turn affect

534 the MSFRC post cracking performance (Figure 5). Due to the brittleness presented by the

535 fibers exposed to $400^{\circ} \mathrm{C}$ (vitreous rupture) it was impossible extract them for tensile

536 strength determination. The absence of fibers in the Zone 1 (up to $1.6 \mathrm{~cm}$ from the border)

537 and the reduced crystallinity measured for the fibers located in the Zone 3, were

538 responsible by the great decrease in the post-cracking behavior of the MSFRC heated up 539 to $400^{\circ} \mathrm{C}$, previously discussed in the item 3.2 .

540

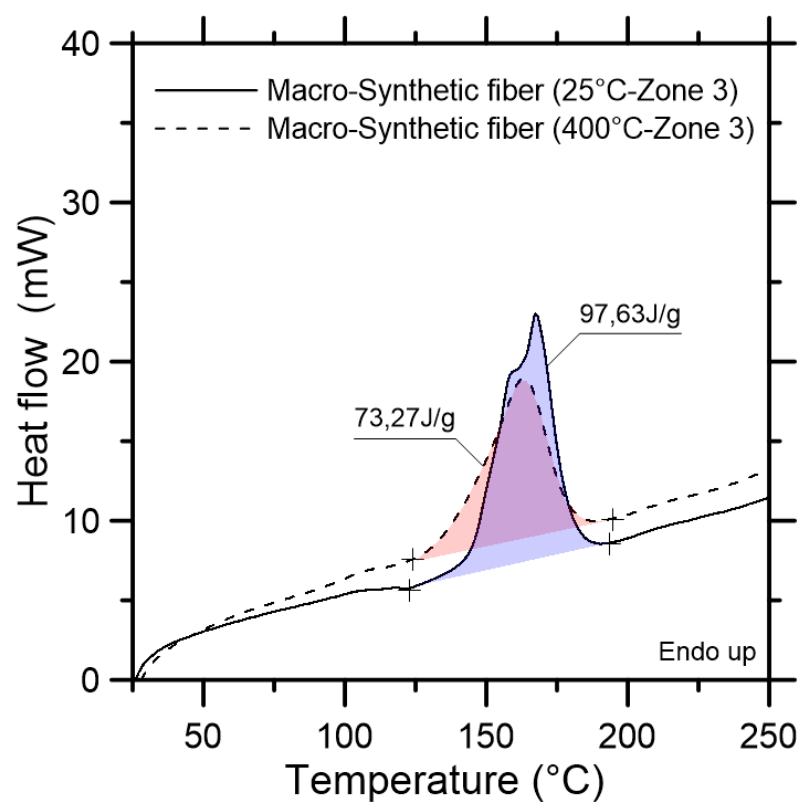

541 (Single column fitting image; preference for color: online only)

542 Figure 12 - Melting enthalpy generated by unheated fibers $\left(25^{\circ} \mathrm{C}\right.$-Zone 3$)$ and by fibers

543 extracted from Zone 3 of the specimens heated up to $400^{\circ} \mathrm{C}$.

545 Micrographs of the Zones 1, 2 and 3 of the MSFRC heated up to $600^{\circ} \mathrm{C}$, revealed the complete absence of fiber reinforcement along the depth of specimens. Such fact indicates

547 that the temperature, even in the Zone 3, exceeded the mark of $300^{\circ} \mathrm{C}$ (beginning of 
548 polypropylene degradation). In addition, the heating regime was long enough to cause

549 fully polymer decomposition. However, it is possible to observe from the 550 thermogravimetric analysis $\left(600^{\circ} \mathrm{C}-\right.$ Zone 3$)$ that the peak of portlandite, at around $430^{\circ} \mathrm{C}$, 551 is still observable (Figure 9). Such observation makes clear that the core reached a 552 temperature very close to $400^{\circ} \mathrm{C}$ while the external faces were submitted to $600^{\circ} \mathrm{C}$. Given 553 the inferences about the thermal gradient experienced by the specimen heated about $554600^{\circ} \mathrm{C}$, the small peak at around $100^{\circ} \mathrm{C}$, observed on the DTG analysis, was attributed to 555 a small rehydration process occurred during the powder sampling.

556 At high temperatures, also the aggregates lose their mechanical properties. In this study, 557 granite aggregates were used as the main component in the concrete composition (see 558 Table 2). As a result, great XRD peaks of quartz, albite, microcline and biotite were 559 observed on the MSFRC diffractograms $\left(25^{\circ} \mathrm{C}\right.$-Zone 3$)$. As reported by Chaki [31], 560 between $400^{\circ} \mathrm{C}$ and $600^{\circ} \mathrm{C}$, a great increase in the volume of connected voids can be 561 expected in granite aggregates. In addition, the $\alpha-\beta$ phase transition of quartz $\left(570^{\circ} \mathrm{C}\right)$, 562 present in granite, can result in an abrupt increase of more than $1 \%$ in the aggregate 563 thermal expansion (between $400^{\circ} \mathrm{C}$ and $600^{\circ} \mathrm{C}$ ) [32]. Such reversible phase change 564 greatly reduces the compressive strength of concrete after the cooling process $[6,33,34]$.

565 The only studied composites subjected to such a severe condition were the MSFRCs 566 heated up to $600^{\circ} \mathrm{C}$. Literature data $[28,27]$ about temperature distribution in cylindrical 567 specimens heated up to $600^{\circ} \mathrm{C}$, suggest temperatures of around $500^{\circ} \mathrm{C}$ for the concrete 568 portion distant $50 \mathrm{~mm}$ from the surface (after one hour at the target temperature). In this 569 context it is acceptable to presume that $\alpha-\beta$ phase transition of quartz occurred only 570 between Zone 1 and 2 in the studied specimens. As reported before, the average tensile 571 strength of the MSFRCs heated up to $600^{\circ} \mathrm{C}$ was $62.6 \%$ lower than that obtained for the 
572 reference specimens $\left(25^{\circ} \mathrm{C}\right)$. Regarding compressive strength and elastic modulus, the

573 losses were of, respectively, $64.9 \%$ and $96.6 \%$ (see Table 4 ).

574 Figure 13 presents correlations of the vertical displacement measurements $\left(\delta_{P}\right)$ with the

575 TCOD values obtained in the BCN tests for all studied temperatures. Given the partial

576 fiber decomposition occurred in the Zone 1 and the low strength capacity of the remaining

577 reinforcement at the Zones 2 and 3 of the MSFCR heated up to $400^{\circ} \mathrm{C}$, great TCOD values

578 are obtained for small displacement increments right after the cracking formation. In

579 addition, greater penetrations of the steel punch are observed for $400^{\circ} \mathrm{C}$ and $600^{\circ} \mathrm{C}$ caused

580 by the crushing of the porous matrix.

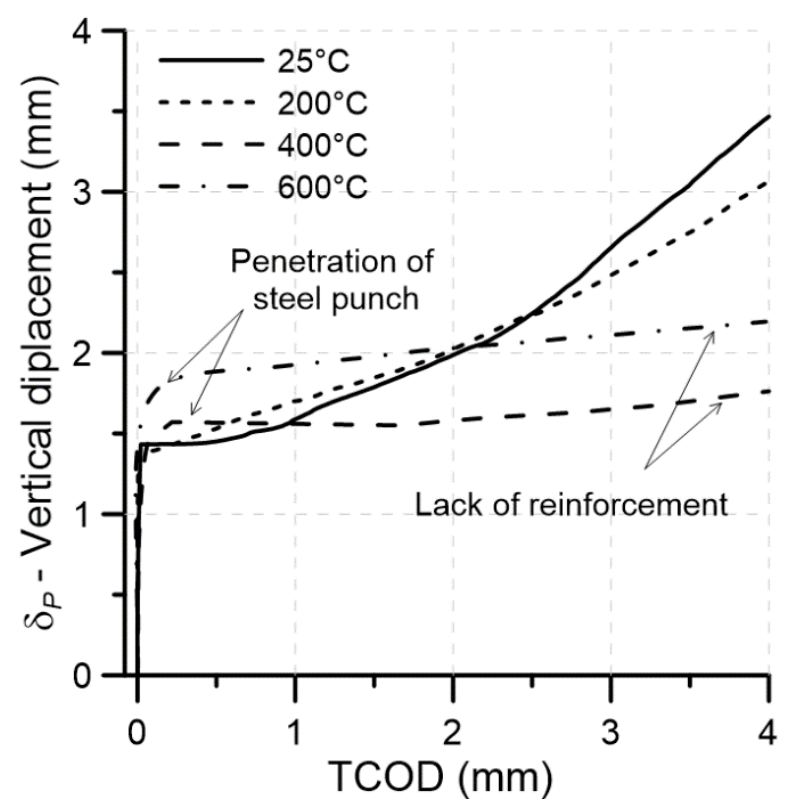

582 (Single column fitting image; grayscale)

583 Figure 13 - Correlation between the vertical displacement $\left(\delta_{P}\right)$ and the TCOD for the

$584 \mathrm{BCN}$ tests performed at room temperature and after heating process up to $200^{\circ} \mathrm{C}, 400^{\circ} \mathrm{C}$ 585 and $600^{\circ} \mathrm{C}$.

586

587 The puncture itself is a feature of the BCN test, however, in the case of residual tests, 588 puncture may result in misleading conclusions, mainly associated with the toughness of 
589 the composite. Greater penetrations result in friction between the steel punch and the

590 concrete matrix that may be confused with the bridging effect caused by the fibers.

\section{4. Conclusions}

592 The effect of temperature on the mechanical behavior of the macro-synthetic fiber

593 reinforced concrete was very similar to that known for conventional concrete and that

594 obtained in other studies concerning mechanical strength and elastic modulus. This is a

595 favorable condition in terms of predicting material behavior.

596 The stress-strain curves obtained from the BCN tests demonstrated that the MSFRC

597 gradually loses tensile strength an energy consumption density with increasing

598 temperature. As well as in the case of compressive strength, the ability of the material to

599 bear stresses is significantly reduced from $400^{\circ} \mathrm{C}$ and above. Such decreases come from

600 the intense decomposition of $\mathrm{CSH}$ and AFt along the specimen depth, even in the inner

601 portions of the specimens (i.e.: Zone 3). The temperature of $570^{\circ} \mathrm{C}$ also represent a critical

602 point since the $\alpha-\beta$ phase transition of quartz damages the structural integrity of the

603 specimens.

604 The residual tensile strength and elastic modulus of the macro-synthetic fibers were not

605 affected by the temperature up to $100^{\circ} \mathrm{C}$. For higher temperatures, however, the

606 reinforcement showed that may lose part of its crystallinity (directly linked to its tensile

607 strength) or even fully decompose, which explain the reduction of the energy

608 consumption density presented by the composite at higher temperatures.

609 The degree of the specimen surface degradation affects the BCN test result in the case of

610 high temperature tests. This effect can be more pronounced for the first crack values given

611 the penetration of the steel punches into the porous matrix. Nevertheless, the gradient of

612 temperature stablished within the specimens may preserve part of the material (i.e.: matrix

613 and fibers), and consequently, the composite post cracking performance. 
614 The constitutive model used to determine the stress-strain curves is sensitive to the

615 damage produced in the different MSFRC specimens by the exposure to high

616 temperatures. Therefore, it capable to reproduce the behavior of the composite material

617 after the event of a fire.

618 In general, the most demanding design conditions for precast tunnel segments occur

619 during transient stages (production, storage, transport, installation, etc). In this context,

620 an additional safety margin should exist in the service stage. Although such safety margin

621 would be reduced in the event of a fire, the remaining resistant capacity may be enough

622 to ensure safety in service depending on the temperature reached. The results herein

623 presented may contribute to the definition of parameters that help evaluating such

624 scenario, which should be addressed in future studies. 
625 Funding: This work was supported by the São Paulo Research Foundation (FAPESP)

626 [grant number \#2015/25457-9 (Dimas Alan Strauss Rambo)];

627 Conflicts of interest: none

628 Acknowledgement: The authors thank Ronaldo dos Anjos for his assistance in editing 629 the images.

630 
[1] J.R. Roesler, S.A. Altoubat, D.A. Lange, K.A. Rieder, G.R. Ulreich, Effect of synthetic fibers on structural behavior of concrete slabs-on-ground, ACI Mater. J. 103 (2006) 3-10.

[2] A.M. Alani, D. Beckett, Mechanical properties of a large scale synthetic fibre reinforced concrete ground slab, Constr. Build. Mater. 41 (2013) 335-344. doi:10.1016/j.conbuildmat.2012.11.043.

[3] A. De La Fuente, R.C. Escariz, A.D. De Figueiredo, A. Aguado, Design of macrosynthetic fibre reinforced concrete pipes, Constr. Build. Mater. 43 (2013) 523-532. doi:10.1016/j.conbuildmat.2013.02.036.

[4] P. Pujadas, A. Blanco, S.H.P. Cavalaro, A. Aguado, S. Grünewald, K. Blom, J.C. Walraven, Plastic fibres as the only reinforcement for flat suspended slabs: Parametric study and design considerations, Constr. Build. Mater. 70 (2014) 88-96. doi:10.1016/j.conbuildmat.2014.07.091.

[5] A. Bentur, S. Mindess, Fibre Reinforced Cementitious Composites, Taylor \& Francis Group (2006) 625.

[6] Z. P. Bažant, M. F. Kaplan, Concrete at High Temperatures: Material Properties and Mathematical Models, Longman (1996) 412.

[7] C. Maluk, L. Bisby, G.P. Terrasi, Effects of polypropylene fibre type and dose on the propensity for heat-induced concrete spalling, Eng. Struct. 141 (2017) 584-595. doi:10.1016/j.engstruct.2017.03.058.

[8] P. Sukontasukkul, W. Pomchiengpin, S. Songpiriyakij, Post-crack (or post-peak) flexural response and toughness of fiber reinforced concrete after exposure to high temperature, Constr. Build. Mater. 24 (2010) 1967-1974. doi:10.1016/j.conbuildmat.2010.04.003.

[9] P. Rinaudo, I. Paya-Zaforteza, P.A. Calderón, Improving tunnel resilience against fires: A new methodology based on temperature monitoring, Tunn. Undergr. Sp. Technol. 52 (2016) 71-84. doi:10.1016/j.tust.2015.11.021. 
[10] J. Gehandler, H. Ingason, A. Lönnermark, H. Frantzich, M. Strömgren, Performancebased design of road tunnel fire safety: Proposal of new Swedish framework, Case Stud. Fire Saf. 1 (2014) 18-28. doi:10.1016/j.csfs.2014.01.002.

[11] B. Chen, J. Liu, Residual strength of hybrid-fiber-reinforced high-strength concrete after exposure to high temperatures, Cem. Concr. Res. 34 (2004) 1065-1069. doi:10.1016/j.cemconres.2003.11.010

[12] G.F. Peng, W.W. Yang, J. Zhao, Y.F. Liu, S.H. Bian, L.H. Zhao, Explosive spalling and residual mechanical properties of fiber-toughened high-performance concrete subjected to high temperatures, Cem. Concr. Res. 36 (2006) 723-727. doi:10.1016/j.cemconres.2005.12.014.

[13] M. Colombo, M. Di Prisco, R. Felicetti, SFRC exposed to high temperature: Hot vs. residual characterization for thin walled elements, Cem. Concr. Compos. 58 (2015) 8194. doi:10.1016/j.cemconcomp.2015.01.002.

[14] D. Choumanidis, E. Badogiannis, P. Nomikos, A. Sofianos. Barcelona test for the evaluation of the mechanical properties of single and hybrid FRC, exposed to elevated temperature. Constr. Build. Mater. 138 (2017) 296-305. doi: 10.1016/j.conbuildmat.2017.01.115

[15] UNE 83515: 2010, Hormigones con fibras. Determinación de la resistencia a fisuración, tenacidad y resistencia residual a tracción. Método Barcelona. The Spanish Association for Standardisation, Madrid, 2010.

[16] UNE 83504: 2004, Hormigones con fibras. Fabricación y conservación de probetas para los ensayos de laboratorio. The Spanish Association for Standardisation, Madrid, 2004. 
[17] A. Blanco, P. Pujadas, S. Cavalaro, A. De La Fuente, A. Aguado, Constitutive model for fibre reinforced concrete based on the Barcelona test, Cem. Concr. Compos. 53 (2014) 327-340. doi:10.1016/j.cemconcomp.2014.07.017.

[18] fib Model Code 2010, International Federation for Structural Concrete, Lausanne, 2013.

[19] ITA, 2004. Guidelines for structural fire resistance for road tunnels, in: Working Group. doi:10.1016/j.tust.2004.01.001

[21] A. R. Estrada, I. Galobardes, A. D. de Figueiredo. Mechanical Characterization of Synthetic Macrofibres. Materials Research, 19 (2016) 711-720. doi: 10.1590/1980-5373MR-2015-0680

[20] H.A. Maddah, Polypropylene as a Promising Plastic: A Review, Am. J. Polym. Sci. 6 (2016) 1-11. doi:10.5923/j.ajps.20160601.01.

[21] N.G. MCCRUM, C. P. BUCKLEY, C. B. BUCKNALL. Principles of Polymer Engineering. Second Edition ed. Oxford, New York: Oxford University Press, 1997.

[22] M. Tian, J. Han, H. Zou, H. Tian, H. Wu, Q. She, W. Chen, L. Zhang, Dramatic influence of compatibility on crystallization behavior and morphology of polypropylene in NBR/PP thermoplastic vulcanizates, J. Polym. Res. 19 (2012). doi:10.1007/s10965011-9745-9.

[23] P. Pujadas, A. Blanco, S.H.P. Cavalaro, A. De La Fuente, A. Aguado, Multidirectional double punch test to assess the post-cracking behaviour and fibre orientation of FRC, Constr. Build. Mater. 58 (2014) 214-224. doi:10.1016/j.conbuildmat.2014.02.023.

[24] A. Blanco, C. Aire, P. Pujadas, S.H.P. Cavalaro, Luong test for the characterization of the shear post-cracking response of fiber reinforced concrete, Constr. Build. Mater. 149 (2017) 207-217. doi:10.1016/j.conbuildmat.2017.05.135.

[25] H.F.W. Taylor, Cement chemistry. 2nd ed., Acad. Press. 20 (1997) 335. doi:10.1016/S0958-9465(98)00023-7. 
[26] J.A. Diaz, J.P. Youngblood, Multivariable dependency of thermal shrinkage in highly aligned polypropylene tapes for self-reinforced polymer composites, Compos. Part A Appl. Sci. Manuf. 90 (2016) 771-777. doi:10.1016/j.compositesa.2016.09.004.

[27] L. Phan, Spalling and mechanical properties of high strength concrete at high temperature, in: Concr. Under Sev. Cond. Environ. Load. (CONSEC '07), 2007: pp. 1595-1608. http://fire.nist.gov/bfrlpubs/build07/art019.html.

[28] F.U.A. Shaikh, V. Vimonsatit, Effect of cooling methods on residual compressive strength and cracking behavior of fly ash concretes exposed at elevated temperatures, Fire Mater. 40 (2016) 335-350. doi:10.1002/fam.2276.

[29] M.M. El-Tonsy, Automatic measurement of the absolute CTE of thin polymer samples: I-effect of multiple processing on thermal expansion of polypropylene films, Pol. Test. 23 (2004) 355-360. doi:10.1016/S0142-9418(03)00102-8

[30] G. Odian, Principles of polymerization, 2004. doi:10.1002/047147875X.ch3.

[31] S. Chaki, M. Takarli, W.P. Agbodjan, Influence of thermal damage on physical properties of a granite rock: Porosity, permeability and ultrasonic wave evolutions, Constr. Build. Mater. 22 (2008) 1456-1461. doi:10.1016/j.conbuildmat.2007.04.002.

[32] P. Hartlieb, M. Toifl, F. Kuchar, R. Meisels, T. Antretter, Thermo-physical properties of selected hard rocks and their relation to microwave-assisted comminution, Miner. Eng. 91 (2016) 34-41. doi:10.1016/j.mineng.2015.11.008.

[33] K.D. Hertz, Concrete strength for fire safety design, Mag. Concr. Res. 57 (2005) 445-453. doi:10.1680/macr.2005.57.8.445.

[34] W.D.A. Rickard, G.J.G. Gluth, K. Pistol, In-situ thermo-mechanical testing of fly ash geopolymer concretes made with quartz and expanded clay aggregates. Cem. Concr. Res. 80 (2016) 33-43. doi:10.1016/j.cemconres.2015.11.006 